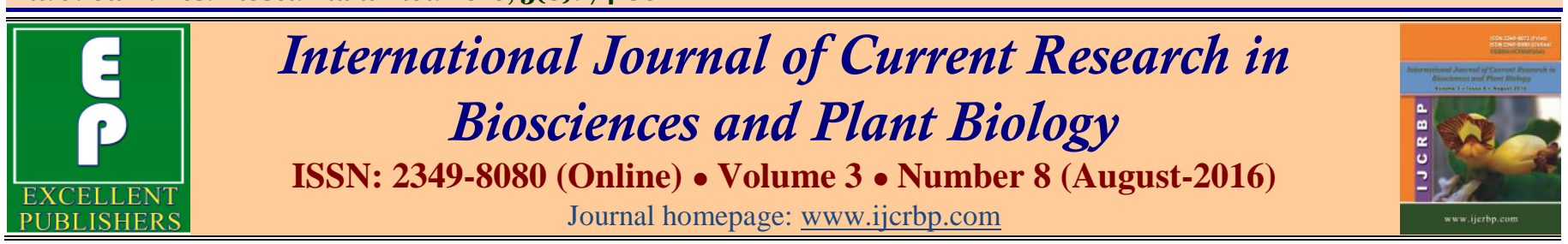

Review Article

doi: http://dx.doi.org/10.20546/ijcrbp.2016.308.012

\title{
Nitrate to Nitrite Ratio in Vegetables: A Systematic Review
}

\author{
Nishant Kumar Gupta, Shine Jones, Binu T. Kuruvilla, Merina Benny \\ and Benny Antony*
}

Arjuna Natural Extracts Ltd., Research and Development Laboratory, Behind ISRO, Keezhmadu, Kerala-683112, India

*Corresponding author.

\begin{abstract}
A b stract
Nitrates and nitrites occur naturally in the environment. They are important plant nutrients and vegetables account for about $70-90 \%$ of the total estimated dietary nitrate intake. Nitrate plays an important role in the nutrition and function of plants. Vegetables rich diet has been described beneficial for longevity and overall health of humans. The positive effects of vegetables may be attributed, in part, to inorganic nitrate present in green leafy vegetables. The nitrate and nitrite level in vegetables varies significantly from type of vegetables, demographic area and season. Nitrate and nitrite content of vegetables has been reviewed and an attempt was made to establish nitrate to nitrite ratio present in vegetables.
\end{abstract}

\section{Article Info}

Accepted: 09 July 2016

Available Online: 06 August 2016

Ke ywords

Nitrate

Nitrite

Nitrate to nitrite ratio

Plant nutrients

Vegetables

\section{Introduction}

Plants and animals require nitrogen to live and grow. However, nitrogen gas, which is abundant in the air we breathe, must first be converted to nitrogen compounds that can be used by plants and animals as sources of nitrogen. This process is called nitrogen fixation. Nitrate and nitrite are two of the nitrogen compounds that are used by plants and animals and eventually return to the air as nitrogen gas. Nitrate and nitrite can also be produced in the body. In nature, plants utilize nitrate as an essential nutrient. Nitrate and nitrite are also used in food preservation, some pharmaceutical drugs, and the production of munitions and explosives (Santamaria, 2006).

Nitrates and nitrites occur naturally in the environment. They are important plant nutrients and can be used in fertilizers. In addition, they can be added to some food products as preservatives. Vegetables account for about $70-90 \%$ of the total estimated dietary nitrate intake. Nitrate plays an important role in the nutrition and function of plants. The nitrate concentration in vegetables depends on a number of factors including species variation, season, light, temperature, method of growth, and fertilizer used. The nitrate and nitrite levels of vegetables after harvesting can be affected by the storage and processing methods (WHO, 2003).

Vegetables rich diet has been described beneficial for longevity and overall health. The positive effects of vegetables may be attributed, in part, to inorganic nitrate $\left(\mathrm{NO}_{3}{ }^{-}\right)$present in green leafy vegetables (Gilchrist et al., 2010). To elicit any biological effects $\mathrm{NO}_{3}{ }^{-}$are likely to be converted to the nitrite $\left(\mathrm{NO}_{2}^{-}\right)$ion in the mouth via oral facultative anaerobic bacteria on the surface of the tongue (Duncan et al., 1995). When swallowed, $\mathrm{NO}_{2}{ }^{-}$is further converted into nitric oxide (NO). The reduction of $\mathrm{NO}_{2}{ }^{-}$to $\mathrm{NO}$ and other reactive nitrogen intermediates are facilitated in low oxygen state which is also called as hypoxia (Bryan, 2006). The production of NO via nitric oxide synthase (NOS) is impaired in hypoxia and, thus, it has been proposed that the $\mathrm{NO}_{3}^{-}-\mathrm{NO}_{2}{ }^{-} \mathrm{NO}$ pathway represents a complementary system for $\mathrm{NO}$ generation 
across a wide range of redox states (Lundberg et al., 2008). NO is an essential physiological signaling molecule with numerous beneficial functions in the body, including the regulation of blood flow, muscle contractility, glucose and calcium homeostasis, and mitochondrial respiration and biogenesis (Dejam et al., 2004).

Nitrates in vegetables have neither taste nor smell but are identified using laboratory tests. Various methods have been developed to determine nitrates in food, water and other matrices. Over the years, analytical techniques, such as spectrophotometry (Huarte-Mendicoa et al., 1997; Nagaraja and Kumar, 2002), potentiometry (PerezOlmos et al., 1997), ion chromatography (Mcmullen et al., 2005), polarography (Ximenes et al., 2000), capillary electrophoresis (Oztekin et al., 2002) as well as highperformance liquid chromatography (Reece and Hird, 2000; Sanderson et al., 1991) have been used.

\section{Role of nitrate and nitrite in human health}

The inorganic nitrate present in certain vegetables and fruits can provide a physiologic substrate for reduction to nitrite, nitric oxide, and other metabolic products that produces vasodilation, decrease blood pressure, and support cardiovascular, metabolic and other body function. Moreover, there are enough evidence for benefits of nitrates in several areas including prevention of microbial infections, cardiovascular diseases, and reduction in the risk of gastric cancer (Santamaria et al., 2006).

It has also been established that dietary supplementation of nitrates can significantly increase the nitrite levels and reduce resting blood pressure in young adults (Bailey et al., 2010; Larsen et al., 2006). Apart from reducing the blood pressure, this dietary nitrate supplementation may have positive effects upon the physiological response to exercise (Bailey et al., 2010; Larsen et al., 2007). In a human study, supplementation with sodium nitrates (Larsen et al., 2007) or beetroot juice (Bailey et al., 2009) resulted in a significant reduction in oxygen uptake during submaximal cycling. In a recent placebo controlled study, it is reported that amaranth extract supplementation significantly increased the nitrate and nitrite levels in blood and saliva (Subramanian and Gupta, 2016). These results are important because the oxygen uptake and work rate relationship have traditionally been considered to be independent of age, health status, and aerobic fitness (Jones and Poole, 2005). The reduction in the oxygen cost of moderate intensity exercise following dietary nitrate supplementation may be a result of a decreased ATP cost of muscle force production (Bailey et al., 2010) and/or enhanced mitochondrial efficiency (Larsen et al., 2011). In a study by Stokes et al, dietary supplementation of nitrate and nitrite in mice has shown to reverse endothelial dysfunction, suppresses microvascular inflammation, and reduces level of $\mathrm{C}$ - reactive protein in mice subjected to a high-cholesterol diet (Stokes et al., 2009).

An Acceptable Daily Intake (ADI) for nitrate of 3.7 $\mathrm{mg} / \mathrm{kg} \mathrm{b.w./day,} \mathrm{equivalent} \mathrm{to} 259 \mathrm{mg}$ nitrate per day for a $70 \mathrm{~kg}$ adult was established by the former Scientific Committee on Food (SCF) and was reconfirmed by the Joint FAO/WHO Expert Committee on Food Additives (JECFA) in 2002 (EFSA, 2008). The JECFA has also set an ADI of $0-0.07 \mathrm{mg} / \mathrm{kg}$ b.w. for nitrite, which is equalent to $0-4.9 \mathrm{mg}$ nitrite for a $70 \mathrm{Kg}$ adult (FAO/WHO, 2003a,b).

\section{Nitrate content of vegetables}

Generally, Leaves contain higher levels of Nitrate whereas seeds and tubers contain lesser level. Humans are exposed to nitrate mainly through the consumption of vegetables, and to a lesser extent water and other foods. Nitrate is also formed endogenously. In contrast exposure to its metabolite nitrite is mainly from endogenous nitrate conversion (EFSA, 2008).

Nitrate is mainly to be found in cell vacuoles and is transported in the xylem. The xylem carries water and nutrients from the roots to the leaves, while the phloem carries the products of photosynthesis from the leaves to the growth points of the plant (i.e. storage organs such as seeds or tubers). This means leaf crops such as cabbage, lettuce and spinach have fairly large nitrate concentrations whereas storage organs such as potato, carrot, and pea and beans have relatively small concentrations (EFSA, 2008).

Vegetables are classified according to the nitrate content as very low $(<200 \mathrm{mg} / \mathrm{kg})$, low $(200-500 \mathrm{mg} / \mathrm{kg})$, middle $(500-1000 \mathrm{mg} / \mathrm{kg})$, high $(1000-2500 \mathrm{mg} / \mathrm{kg})$ and very high $(>2500 \mathrm{mg} / \mathrm{kg}) \quad$ (Santamaria, 2006). This classification is summarized in Table 1.

The distribution of nitrate is not even across the product, e.g. removal of stem and midrib resulted in a decrease of nitrate content by $30-40 \%$ in lettuce and spinach. On the other hand, nitrate content was found to decrease by 20 
to $62 \%$ after peeling of potatoes, bananas, melons and beetroot. Nitrate is soluble in water and washing of leafy vegetables can reduce nitrate levels by $10-15 \%$ (Chung et al., 2003; EFSA, 2008).

Different studies have shown reduction of nitrate levels (16 to $79 \%$ loss) when vegetables such as peas, cabbage, beans, carrots, potatoes, spinach, endives, and celery leaves are cooked in water. For potatoes, a study found that the greatest decrease in reducing nitrate (36-58\%) and nitrite $(82-98 \%)$ was observed when peeled potatoes were boiled in water compared to steaming (Stopes et al., 1988). Spinach is regularly regarded as one of the highest nitrate accumulators. Its distinctive shoot structure, consisting of petioles, where nitrate passes through and accumulates, and leaf-blades, where nitrate reduction and assimilation take place, might be one of the reasons for spinach's relatively high nitrate concentration. Certain vegetables, because of a very efficient uptake system, an inefficient reductive system, or an unfavorable combination of both, tend to accumulate more nitrate than others (Maynard et al., 1976).

Table 1. Classification of vegetables on the basis of nitrate content.

\begin{tabular}{|c|c|}
\hline $\begin{array}{l}\text { Nitrate content } \\
(\mathrm{mg} / \mathrm{kg})\end{array}$ & Vegetables \\
\hline Very low $(<200)$ & $\begin{array}{l}\text { Artichoke, Asparagus, Broad bean, Brussels sprouts, Garlic, Onion, Green bean, Melon, Mushroom, Pea, } \\
\text { Pepper, Potato, Summer squash, Sweet potato, Tomato, Watermelon }\end{array}$ \\
\hline Low $(200-500)$ & Broccoli, Carrot, Cauliflower, Cucumber, Pumpkin, Puntarelle \\
\hline Middle (500-1000) & Cabbage, Cima di rapa, Dill, Radicchio, Savoy cabbage, Turnip \\
\hline $\operatorname{High}(1000-2500)$ & Celeriac, Chinese cabbage, Endive, Escarola, Fennel, Kohlrabi, Leaf chicory, Leek, Parsley \\
\hline Very high $(>2500)$ & Beetroot, Celery, Chervil, Cress, Lamb's lettuce, Lettuce, Radish, Rocket, Spinach, Swiss chard \\
\hline
\end{tabular}

\section{Nitrite content of vegetables}

The nitrite concentrations in fresh, undamaged vegetables are usually very low but under adverse postharvest storage conditions nitrite concentration can increase in vegetables as a result of bacterial or endogenous nitrate reductase reducing the nitrate to nitrite. Under refrigerated storage, the endogenous nitrate reductase in vegetable is inactivated. However, high levels of nitrite have been found in homemade vegetable purees even after refrigerated storage for only 12 hours or more. Presumably pureeing releases endogenous nitrate reductase causing excessive formation of nitrite. Nitrite accumulation is inhibited under frozen storage (WHO, 2003; EFSA, 2008).

A lot of studies have been conducted in European countries to determine the nitrite intake as a part of daily food. Based on national average food consumption data of France, average nitrite intake was $1.88 \mathrm{mg} /$ day, $43 \%$ from vegetables; $28 \%$ from cured meats and $5 \%$ from cereal products (Cornee et al., 1992). In a duplicate portion study in The Netherland, the highest recorded nitrite intake was $0.7 \mathrm{mg} /$ day (Ellen et al., 1990).

In UK, the estimated mean dietary nitrite intake using the Total Diet Study ranged from 2.4-4.2 mg/day. However, this is recognized to be an overestimate as all samples containing undetectable levels of nitrite were assumed to contain nitrite at the limit of detection of the method used $(1 \mathrm{mg} / \mathrm{kg})$. In an earlier study in 1979 , the estimated mean dietary nitrite concentration was $0.87 \mathrm{mg} /$ day using methods with a lower limit of detection of 0.2 or 0.4 $\mathrm{mg} / \mathrm{kg}$ (U.K. Ministry of Agriculture, Fisheries and Food, 1992).

Recent data on nitrite contents of vegetables has been summarized in Table 2. Data derived from Anonymous (1993); Ansorena and Merino (1992); Burt (1993; 1994); Cornee et al. (1992); Meah et al. (1994); Mortensen and Larsen (1989) U.K. Ministry of Agriculture, Fisheries and Food (1992).

Table 2. Nitrite levels in vegetables.

\begin{tabular}{ll}
\hline Vegetables & Nitrite content $\mathbf{( m g / K g )}$ \\
\hline Beans (Green) & ND \\
Beetroot & ND-8 \\
Broccoli & $2-4$ \\
Cabbage (Green) & ND-2 \\
Carrot & ND-2 \\
Celery (White) & ND-8 \\
Cucumber & 3 \\
Potatoes & ND-19 \\
Spinach & ND-26 \\
Tomato & ND-4 \\
\hline ND: Not detected &
\end{tabular}




\section{Nitrate to nitrite ratio}

The presence of nitrate and nitrite in vegetables and other food materials have been described in large number of scientific papers. The ratio of nitrate to nitrite has not been established till now as per our knowledge. Since nitrate as well as nitrite has significant impact on human health, it is important to review the ratio of nitrate to nitrite present in the vegetables. Nitrate and Nitrite content varies from place to place and from vegetable to vegetable. According to earlier surveys high values of nitrate anion concentration can be found in dill leaves (Anethum graveolens), lettuce leaves (Lactuca sativa), cabbage leaves (Brassica oleracea var. capitata), spinach leaves (Spinacia oleracea), amaranth (Amaranthus spp.), carrot root (Daucus carota subsp. sativus) and beetroot (Beta vulgaris). In the case of nitrite levels, most of the samples, if not all, fall under the detection or quantification limits (Croitoru et al., 2015).

Majority of the studies performed before 2001 has reported a low level of nitrate and nitrite in the vegetables (Yordanov et al., 2001) whereas the recently reported studies have shown higher values of nitrate and nitrite for the same vegetables (Santamaria, 2006). The higher values reported in the recent studies may be due to the development of sophisticated technology and new analytical methods with higher limit of detection (LOD) and limit of quantification (LOQ). A comprehensive data on nitrate to nitrite ratio has been presented in Table 3 .

Table 3. Nitrate to nitrite ratio in vegetables.

\begin{tabular}{|c|c|c|c|c|c|}
\hline $\begin{array}{l}\text { S. } \\
\text { No. }\end{array}$ & Vegetables & $\begin{array}{l}\text { Nitrate } \\
(\mathrm{mg} / \mathrm{kg})\end{array}$ & $\begin{array}{l}\text { Nitrite } \\
(\mathrm{mg} / \mathrm{kg})\end{array}$ & $\begin{array}{l}\text { Nitrate: } \\
\text { Nitrite ratio }\end{array}$ & Reference \\
\hline \multirow[t]{3}{*}{1} & Carrot (obtained in local market) & 123.1 & 0.82 & 150: 1 & Yordanov et al. (2001) \\
\hline & Carrot (Home grown) & 29.4 & 0.39 & $75: 1$ & Yordanov et al. (2001) \\
\hline & Carrot (Austria) & 1500 & - & - & Santamaria (2006) \\
\hline \multirow[t]{4}{*}{2} & Beetroot (Home grown) & 38.9 & 0.45 & $86: 1$ & Yordanov et al. (2001) \\
\hline & Red Beetroot (Austria) & 4500 & - & - & Santamaria (2006) \\
\hline & Red Beetroot (Germany) & 3000 & - & - & Santamaria (2006) \\
\hline & Red Beetroot (Netherlands) & 3500 & - & - & Santamaria (2006) \\
\hline 3 & Currants, gooseberries & 36 & - & - & Nabrzyski and Gaiewaska (1994) \\
\hline 4 & Chinese kale & 2340 & 83.8 & $28: 1$ & Chou et al. (2003) \\
\hline 5 & Organic non-heading Chinese cabbage & 2860 & 41 & $70: 1$ & Chou et.al. (2003) \\
\hline \multirow[t]{2}{*}{6} & Spinach & 110 & 0.84 & $130: 1$ & Jaworska and Kmiecik (1999) \\
\hline & $\begin{array}{l}\text { Spinach (obtained } \\
\text { in local market) }\end{array}$ & 860.1 & 7.44 & $115: 1$ & Yordanov et al. (2001) \\
\hline \multirow[t]{3}{*}{7} & $\begin{array}{l}\text { French bean (obtained } \\
\text { in local market) }\end{array}$ & 39.9 & 0.59 & $67: 1$ & Yordanov et al. (2001) \\
\hline & French bean (Home grown) & 13.3 & 0.15 & $88: 1$ & Yordanov et al. (2001) \\
\hline & Organic green bean sprout & 4410 & 85.1 & $52: 1$ & Chou et al. (2003) \\
\hline 8 & Lima Been (Frozen) & 27 & 1.1 & $24: 1$ & Siciliano et al. (1975) \\
\hline 9 & Green bean & 37.6 & 7.6 & $5: 1$ & Afzali and Elahi (2014) \\
\hline \multirow[t]{4}{*}{10} & Onion (Winter) & 14 & 0.3 & 47: 1 & Siciliano et al. (1975) \\
\hline & $\begin{array}{l}\text { Green onion (obtained } \\
\text { in local market) }\end{array}$ & 30.1 & 0.30 & $100: 1$ & Yordanov et al. (2001) \\
\hline & Green onion (Home grown) & 11.2 & - & - & Yordanov et al. (2001) \\
\hline & Onion & 12.20 & 6.09 & $2: 1$ & Afzali and Elahi (2014) \\
\hline \multirow[t]{2}{*}{11} & $\begin{array}{l}\text { Radish (obtained } \\
\text { in local market) }\end{array}$ & 737.2 & 5.93 & $124: 1$ & Yordanov et al. (2001) \\
\hline & Radish leaves & 1521.13 & - & - & Jana and Moktan (2013) \\
\hline \multirow[t]{2}{*}{12} & $\begin{array}{l}\text { Paprika (obtained } \\
\text { in local market) }\end{array}$ & 38.1 & 0.48 & $79: 1$ & Yordanov et al. (2001) \\
\hline & Paprika (Home grown) & 10.1 & 0.14 & $72: 1$ & Yordanov et al. (2001) \\
\hline \multirow[t]{5}{*}{13} & $\begin{array}{l}\text { Tomato (obtained } \\
\text { in local market) }\end{array}$ & 5.2 & - & - & Yordanov et al. (2001) \\
\hline & Tomatoes (Variety L2 Minidelicia) & 112.5 & 0.3 & $375: 1$ & Simion et al. (2008) \\
\hline & Tomato & 4.3 & 0.3 & $14: 1$ & Susin et al. (2006) \\
\hline & Tomato & 8.02 & 0.03 & $267: 1$ & Andrei and Beceanu (2012) \\
\hline & Tomato & 7.82 & 1.81 & $4: 1$ & Rezaei et al. (2014) \\
\hline
\end{tabular}




\begin{tabular}{llllll}
\hline $\begin{array}{l}\text { S. } \\
\text { No. }\end{array}$ & Vegetables & $\begin{array}{l}\text { Nitrate } \\
(\mathbf{m g} / \mathbf{k g})\end{array}$ & $\begin{array}{l}\text { Nitrite } \\
(\mathbf{m g} / \mathbf{k g})\end{array}$ & $\begin{array}{l}\text { Nitrate: } \\
\text { Nitrite ratio }\end{array}$ & Reference \\
\hline 14 & 17.5 & 0.23 & $76: 1$ & Yordanov et al. (2001) \\
& $\begin{array}{l}\text { Strawberry (obtained } \\
\text { in local market) }\end{array}$ & & & & \\
15 & $\begin{array}{l}\text { Potato (obtained } \\
\text { in local market) }\end{array}$ & 40.2 & 0.66 & $60: 1$ & Yordanov et al. (2001) \\
& $\begin{array}{l}\text { Potato (Home grown) } \\
\text { white potato tuber }\end{array}$ & 17.6 & - & - & Yordanov et al. (2001) \\
& Chinese spinach & 12.67 & 0.06 & $208: 1$ & Croitoru et al. (2015) \\
16 & $>3500$ & $<1$ & $3500: 1$ & Chung et al. (2011) \\
17 & Watermelon & 26.61 & 5.5 & $4.84: 1$ & Rezaei et al. (2014) \\
18 & Cantaloupe & 58.95 & 28.36 & $2.32: 1$ & Rezaei et al. (2014) \\
19 & Melon & 33.64 & 7.65 & $4.40: 1$ & Rezaei et al. (2014) \\
20 & Mushroom & 63 & 0.8 & $78: 1$ & Siciliano et al. (1975) \\
21 & Cucumber & 24 & 0.5 & $48: 1$ & Siciliano et al. (1975) \\
& Spezaei et al. (2014) \\
22 & Sprouts, soyabean (Winter) & 42.7 & 9.03 & $4.73: 1$ & Res \\
& Sprouts, soyabean (Summer) & 63 & 0.8 & $78: 1$ & Chung et al. (2003) \\
\hline
\end{tabular}

\section{Conclusion}

Nitrates and nitrites present in vegetables have remarkable health benefits. The level of nitrates as well as nitrites varies significantly from vegetable to vegetable and demographic area. Green leafy vegetables and beetroot contain highest percentage of nitrates. The ratio of nitrates to nitrites varies from as low as (2:1) present in onion to as high as (3500:1) in Chinese spinach.

\section{Conflict of interest statement}

Authors declare that they have no conflict of interest.

\section{References}

Afzali, S.F., Elahi, R., 2014. Measuring nitrate and nitrite concentrations in vegetables, fruits in Shiraz. J. Appl. Sci. Environ. Manage. 18(3), 451-457.

Andrei, C., Beceanu, D., 2012. The studies on the dynamics content of nitrates and nitrites from tomatoes and products resulting from technological flow of obtaining tomato juice. University of Agricultural Sciences and Veterinary Medicine Iasi. Seria Agronomie. 55/2012.

Anonymous., 1993. Les nitrates dans les légumes. Test-Achats Magazine. 359, 28-33.

Ansorena Miner, J., Merino Merino, D., 1992. Contenido en nitratos de las hortalizas. Influencia de factores genéticos $\mathrm{y}$ de iluminación. Communication presented at the Congreso International de Quimica de la Anque. Burgos. 21-23 October, 1992.

Bailey, S.J., Fulford, J., Vanhatalo, A., Winyard, P.G., Blackwell, J.R., DiMenna, F.J., Wilkerson, D.P., Benjamin, N., Jones, A.M., 2010. Dietary nitrate supplementation enhances muscle contractile efficiency during knee-extensor exercise in humans. J Appl
Physiol.109,135-48.

Bailey, S.J., Winyard, P., Vanhatalo, A., Blackwell, J.R., DiMenna, F., Wilkerson, D.P., Tarr, J., Benjamin, N., Jones, A.M., 2009. Dietary nitrate supplementation reduces the $\mathrm{O}_{2}$ cost of sub-maximal exercise and enhances exercise tolerance in humans. J.Appl Physiol. 107,114455.

Bryan, N.S., 2006. Nitrite in nitric oxide biology: cause or consequence? A systems-based review. Free Radic Biol Med. 41,691-701.

Burt, R., 1993. Intakes of nitrate by upper range consumers of certain vegetables. Paper submitted to the Commission of the European Communities, DGIII/E/1, $14^{\text {th }}$ December.

Burt, R., 1994. Intakes of nitrate by upper range consumers of certain vegetables. Paper submitted to the Commission of the European Communities, DGIII/E/I, $17^{\text {th }}$ January.

Chou, S.S., Chung, J.C., Hwang, D.F., 2003. A High Performance Liquid Chromatography Method for Determining Nitrate and Nitrite Levels in Vegetables. J. Food Drug Anal. 11 (3), 233-238.

Chung, S.W.C., Tran, J.C.H., Tong, K.S.K., Chen, M.Y.Y., Xiao, Y., Ho, Y.Y., Chan, H.Y., 2011. Nitrate and Nitrite levels in commonly consumed vegetables in Hong Kong. Food Addit. Contam. 4 (1), 34-41

Chung, S.Y., 2003. Survey of nitrate and nitrite contents of vegetables grown in Korea. Food Addit. Contam. 20(7), 621-628.

Cornee, J., Lairon. D., Velema, J., Guyader, M., Berthezene, P., 1992. An estimate of nitrate, nitrite and $\mathrm{N}$ nitrosodimethylamine concentrations in French food products or food groups. Sci. Aliments. 12, 155-197.

Croitoru, M.D., Fulop, I., Miklos, A., Hosszu, B.,Tatar, VL., Muntean D.L., 2015. Presence of Nitrate and Nitrite in Vegetables grown for Self-Consumption, Farmacia-2015. 63,4 .

Dejam, A., Hunter, C.J., Schechter, A.N., Gladwin, M.T., 2004. Emerging role of nitrite in human biology. Blood Cells Mol. Dis. 32, 423-429.

Duncan, C., Dougall, H., Johnston, P., Green, S., Brogan, R., 
Smith, L., Golden, M., Benjamin, N., 1995. Chemical generation of nitric oxide in the mouth from the enterosalivary circulation of dietary nitrate. Nat. Med. 1, 546-551.

EFSA, 2008. Opinion of the Scientific Panel on Contaminants in Food Chain on a request from the European Commission to perform a scientific risk assessment on nitrate in vegetables. EFSA J. 69, 1-79.

Ellen, G., Egmond, E., Van Loon, J.W., Sahertian, E.T., Tolsma, K., 1990. Dietary intakes of some essential and non-essential trace elements. nitrates, nitrites and nitrosamines by Dutch adults: estimated via a 24 hour duplicate portion study. Addit. Contam. 7, 207-221.

FAO/WHO (Food and Agriculture Organisation of the United Nations/World Health Organization). 2003a. Nitrate (and potential endogenous formation of $\mathrm{N}$-nitrosocompounds). WHO Food Additive series 50, Geneva: World Health Organisation.

FAO/WHO (Food and Agriculture Organisation of the United Nations/World Health Organization). 2003b. Nitrite (and potential endogenous formation of N-nitroso compounds). WHO Food Additive series 50, Geneva: World Health Organisation.

Gilchrist, M., Winyard, PG., Benjamin, N., 2010. Dietary nitrate: good or bad? J Nitric Oxide. 22,104-9.

Huarte-Mendicoa, J.C., Astiasaran, I., Bello, J., 1997. Nitrate and nitrite levels in frozen broccoli. Effect of freezing and cooking. Food Chem. 58, 39-42.

Jana, J.C., Moktan, P., 2013. Nitrate concentration of leafy vegetables: A survey of nitrite concentrations in retail fresh leafy vegetables from daily markets of different locations. ISABB Journal of Food and Agriculture Science. 3 (1), 1-5.

Jaworska, G., Kmiecik, W., 1999. Content of selected Mineral Compounds, Nitrates III and V, and Oxalates in spinach (Spinacia oleracea L.) and New Zealand spinach (Tetragonia expansa Murr.) from spring and autum growing seasons. Elec. J. Pol. Agric.Univ. s. Food Sci. Technol. $240 \quad$ (available at: http://www.ejpau.media.pl/series/volume2/issue2/food/art - 03.html)

Jones, A.M., Poole, D.C., 2005. Oxygen uptake dynamics: From muscle to mouth an introduction to the symposium. Med. Sci. Sport Exerc. 37, 1542-1550.

Larsen, F.J., Ekblom, B., Sahlin, K., Lundberg, J.O., Weitzberg, E., 2006. Effects of dietary nitrate on blood pressure in healthy volunteers. N. Engl. J. Med. 355, 2792-2793.

Larsen, F.J., Ekblom, B., Sahlin, K., Lundberg, J.O., Weitzberg, E., 2007. Effects of dietary nitrate on oxygen cost during exercise. Acta Physiol. (Oxf) . 191, 59-66.

Larsen, F.J., Schiffer, T.A., Borniquel, S., Sahlin, K., Ekblom, B., Lundberg, J.O., Weitzberg, E., 2011. Dietary inorganic nitrate improves mitochondrial efficiency in humans. Cell Metab. 13, 149-159.

Lundberg, J.O., Weitzberg, E., Gladwin, M.T., 2008. The nitrate-nitrite-nitric oxide pathway in physiology and therapeutics. Nat. Rev. Drug Discov. 7, 156-167.

Maynard, D.N., Barker, A.V., Minotti, P.L., Peck, N.H., 1976. Nitrate accumulation in vegetables. Adv. Agron. 28, 71118.

Mcmullen, S.E., Cassanova, J.A., Gross, L.K., Schenck, F.J., 2005. Ion chromatographic determination of nitrate and nitrite in vegetable and fruit baby foods. J. AOAC Int. 88, 1793-1796.

Meah, M.N., Harrison, N., Davies, A., 1994. Nitrate and nitrite in foods and diet. Food Addit. Contam. 11, 519-532.

Mortensen, G.K., Larsen, E.II., 1989. Ovorvagningsprogram for nitrat i grøntsager, 1984-1988. 1988. Nitrat i friske grøntsager. Report No. F 89004 from Levnedsmiddelstyrelsen, Denmark.

Nabrzyski, M., Gaiewaska, R., 1994. The Content of nitrate and nitrites in fruits, Vegetables and other food stuffs. Rocz Panstw Zakl Hig. 45 (3), 167-180.

Nagaraja, P., Kumar, M.S.H., 2002. Spectrophotometric determination of nitrate in polluted water using a new coupling reagent. Anal. Sci. 18, 355-357.

Oztekin, N., Nutku, M.S., Erim, F.B., 2002. Simultaneous determination of nitrite and nitrate in meat products and vegetables by capillary electrophoresis. Food Chem. 76, 103-106.

Perez-Olmos, R., Herrero, R., Lima, J.L.F.C., Montenegro, M.C.B.S.M., 1997. Sequential potentiometric determination of chloride and nitrate in meat products. Food Chem. 59, 305-311.

Reece, P., Hird, H., 2000. Modification of the ion exchange HPLC procedure for the detection of nitrate and nitrite in dairy products. Food Addit. Contam. 17, 219-222.

Rezaei, M., Fani, A., LatifMoini, A., Mirzajani, P., Malekirad, A.A., Rafiei, M., 2014. Determining nitrate and nitrite content in beverages, fruits, vegetables, and stews marketed in Arak, Iran. Int. Scholarly Res. Notices. 1-5. http://dx.doi.org/10.1155/2014/439702

Sanderson, J.E., Rassconsaul, J., Lee, K., 1991. Nitrate analysis in meat. Comparison of two methods. J. Food Sci. $56,1123-1124$.

Santamaria, P., 2006. Nitrate in vegetables: toxicity, content, intake and EC regulation, J. Sci. Food Agric. 86, 10-17.

Siciliano, J., Krulick, S., Heisler, E.G., Schwartz, J.H., White Jr, J.W., 1975. Nitrate and nitrite content of some fresh and processed market vegetables. J. Agric. Food Chem. 23, 461-464.

Simion, V., Campeanu, G.H., Vasile, G., Artimon, M., Catana, L., Negoiţa, M., 2008. Nitrate and nitrite accumulation in tomatoes and derived products. Rom. Biotech. Lett. 13 (4), 3785-3790.

Stokes, K.Y., Dugas, T.R., Tang, Y., Garg, H., Guidry, E., Bryan, N.S., 2009. Dietary nitrite prevents hypercholesterolemic microvascular inflammation and reverses endothelial dysfunction. Am. J. Physiol. Heart Circ. Physiol. 296, H1281-H1288.

Stopes, C., Woodward, L., Forde, G., Vogtman, H., 1988. The nitrate content of vegetable and salad crops offered to the consumer as from "organic" or 
"conventional" production systems. Biol. Agric. Hort. 5(3), 215-222.

Subramanian, D., Gupta, S., 2016. Pharmacokinetic study of amaranth extract in healthy humans: A randomized trial. Nutrition. 32(7-8), 748-753.

Susin, J., Kmecl, V., Gregorcic, A., 2006. A survey of nitrate and nitrite content of fruit and vegetables grown in Slovenia during 1996-2002. Food Addit. Contam. 23(4), 385-390.

U.K. Ministry of Agriculture, Fisheries and Food. 1992. Nitrate, nitrite and N-nitrosocompounds in Food: Second
Report. Food Surveillance Paper No-32. HMSO, London.

WHO, 2003. Nitrate and nitrite-intake assessment. In: Safety Evaluation of Certain Food Additives (Food Additives Series 50). WHO, Geneva.

Ximenes, M.I.N., Rath, S., Reyes, F.G.R., 2000. Polarographic determination of nitrate in vegetables. Talanta. 51, 49-56.

Yordanov, N.D., Novakova, E., Lubenova, S., 2001. Consecutive estimation of nitrate and nitrite ions in vegetables and fruits by electron paramagnetic resonance spectrometry. Anal. Chim. Acta. 437, 131-138.

\section{How to cite this article:}

Gupta, N. K., Jones, S., Kuruvilla, B. T., Benny, M., Antony, B., 2016. Nitrate to nitrite ratio in vegetables: A systematic review. Int. J. Curr. Res. Biosci. Plant Biol. 3(8), 74-80.

doi: http://dx.doi.org/10.20546/ijcrbp.2016.308.012 